\title{
Determinants of e-resource usage by open distance learning university students
}

\author{
Peng Long $\mathrm{Ng}^{1}$ and Andrew K.G. $\operatorname{Tan}^{2}$ \\ ${ }^{1}$ Wawasan Open University Malaysia \\ $17 \& 19$, Jalan Jaya 2, Taman Jaya, Skudai, \\ 81300 Johor Bahru, Johor, MALAYSIA \\ ${ }^{2}$ School of Social Sciences, Universiti Sains Malaysia \\ 11800 Minden, Penang, MALAYSIA \\ e-mail: plng@wou.edu.my (corresponding author); atan@usm.my
}

\begin{abstract}
This study examines the association between socio-demographic and programme-related factors and usage likelihoods of two types of e-resource platforms (E-library and Learning Management System (LMS)) by Open Distance Learning (ODL) university students. Based on stratified random sampling measures, primary data were collected from 1,192 student respondents from an ODL university in Malaysia. Information on socio-demographic characteristics (age, ethnicity, gender, education level, household income) and programmerelated factors (location of regional centre, year registered, programme of study, attendance to orientation session) were elicited. Logistic regression analysis was applied on two separate outcome variables with affirmative $(Y=1)$ and negative $(Y=0)$ responses reflecting E-library and LMS utilisation. Results indicate that students who are more likely to use E-library consist of older, recent enrolees, and orientation session participants, while Chinese students are less likely to use the facility than their respective peers. Positive LMS usage likelihoods are associated with students who are younger, female, Sijil Tinggi Pelajaran Malaysia (STPM) holders, orientation programme attendees, Science and Technology majors, registered five or more years, and those hailing from the regional centres of Ipoh and Kuala Lumpur. Students from low income bracket households are less likely to utilise LMS than others. Based on these outcomes, several observations are noted to provide university policy-makers with a better understanding of the determinants of $E$ library and LMS utilisation among ODL university students.
\end{abstract}

Keywords: E-library; E-resources; Learning Management System; Open Distance Learning; Usage likelihoods.

\section{INTRODUCTION}

Universities offering Open Distance Learning (ODL) programmes are leveraging on the advancement of technology to make higher education more accessible to a larger learning community. Custom-made online learning support services (henceforth referred to as eresources), such as the E-library and Learning Management System (LMS), are among the teaching and learning tools developed to overcome limitations in conventional classroom 
learning settings (Ng and Kong 2012; Ping, Muthuveloo and Hooi 2012). In expending much financial investment on these e-resources, ODL universities hope that the learning process can be extended beyond the normal classroom settings with no scheduled time-tables required, thus enabling a more accommodating and less stressful learning experience (Low, Ong and Low 2005).

There exists a large body of literature investigating subjects related to e-resource usage in ODL programmes. These studies can be broadly categorised into those examining the role of tutors (McPherson and Nunes 2003; 2004; Rosell-Aguilar 2007), student perceptions (Mason and Weller 2000; Picciano 2002; Zhang, Perris and Yeung 2005; Green, Fethi and Danton 2012; Swart 2015), educational technology or teaching methods (Andersson 2010; Mallinson and Krull 2013), and management strategies (Ghavifekr and Hussin 2010). Others consider the effect of student computer competencies in relation to computer usage and its applications ((Koustriava and Papadopoulos 2014).

Despite the abundance of studies examining the various topics related to e-resource usage in ODL environments, there remains a dearth of analysis on the determinants of e-resource usage among ODL university students. In particular, there exists scant analysis on the association between socio-demographic and programme-related factors in determining eresource usage within the Malaysian ODL university context. As a result, user-specificity implied by students' socio-demographical and programme-related factors are unknown thus far. A better understanding of such determinants allows ODL university policy-makers with baseline information on utilisation patterns whilst justifying the financial investments on these e-resources.

This study contributes to the body of literature by identifying the determinants of eresource usage among ODL university students. Specifically, the study examines the effects of socio-demographic and programme-related factors on usage likelihoods of two types of e-resources (E-library and LMS) by ODL university students.

\section{CONTEXT OF THE STUDY}

As one of two Malaysian universities offering ODL, Wawasan Open University (WOU) was established as a private non-profit higher learning education institution in August 2006, with its first student intake in January 2007. In accordance with its primary vision, the university aspires to be a vibrant learning community that inspires learning, supports innovation, and nurtures all-round personal growth (Wawasan Open University 2015a). The university has five regional offices located throughout Malaysia: Penang, Kuala Lumpur, Ipoh, Johor Bahru, and Kuching. These regional offices serve as a platform for face-to-face interactions between students and tutors. These regional offices also function as contact points for counselling, informal peer support, and group study sessions as they are equipped with various facilities such as tutorial rooms, computer laboratories, audiovisual equipment, reference books, and other study materials (Ping et al. 2012).

By July 2011, more than 8,300 students have undertaken the flexible technology-enhanced ODL education delivery, with 3,787 students actively registered in courses leading to the award of 38 named qualifications at the sub-degree, degree and masters level. Student age varies from 21 to 72 (72.7 percent within the 21-35 years age group), and the gender balance is 50.7 percent males to 49.3 percent females. About 85.5 percent are undertaking undergraduate programmes, while 14.5 percent are registered for post-graduate 
programmes offered through the School of Business and Administration, School of Science \& Technology, School of Foundation \& Liberal Studies, and the School of Education, Languages and Communication (Wawasan Open University Annual Report 2013; Wong and Liew 2013).

The WOU E-library allows students to gain remote access to a vast array of organised repository of information. Students are able to conduct online search and gain access to books, journals, magazines, encyclopaedias, news portals, staff papers, project reports, audio-visual materials, and bibliographic databases. Other virtual services include allowing staff and students to renew or reserve books/materials online and to check their borrowing records. An inter-library loan service and links to Internet reference resources and other libraries' catalogues are also accessible via the E-library.

The LMS at WOU is known as WawasanLearn. As an online system to enhance long distance learning and supplement face-to-face tutorials, it contains web components, such as templates for content pages, announcements, discussion forums, quizzes, and exercises to engage students with course materials. The platform allows students to collaborate and interact with their tutors and fellow students regularly. Other features include provision of e-learning content, communication tools, and user groups' administration (Wawasan Open University 2015b).

\section{LITERATURE REVIEW}

While studies examining the determinants of e-resource (e.g., E-library or LMS) usage among ODL university students are scant, there exist myriad studies focusing on information technology, Internet, information systems, digital libraries and conventional library usage by students at institutions of higher learning. Therefore, insights from the literature are sought from a wider array of sources in examining the roles of sociodemographic and programme-related factors on e-resource usage in the current study.

For example, the association between age and computer attitudes and technology adoption is mixed. In studies where samples comprise of individuals of similar age groups, the absence of any significant association between age and attitudes might result (Teo 2008). However, unlike those in conventional universities who share a more homogeneous age range, ODL students often comprise of working adults with more diverse age groups. In such cases, the age factor has been identified as a barrier to technology adoption, whereby older individuals are often less receptive towards technology compared to younger persons who place a higher emphasis on the extrinsic values of technology uptake (Claar, Dias and Shields 2014; Niehaves and Plattfaut 2014; van Deursen and van Dijk 2014). Hence, it is hypothesised that older (young) individuals may be less (more) likely to indulge in e-resource usage.

Enoch and Soker (2006) and Bennett et al. (2008) argue that while university students may be utilising a wide array of technologies in their everyday lives, there remain issues pertaining to usage and familiarity with technology and its relationship with cultural/ethnic backgrounds. On this basis, the unique multi-ethnic composition of students in Malaysia, consisting of the three main ethnic groups of Malays, Chinese, and Indians, and a proportion of other races, allows for the possibility that differences within each ethnic group may influence e-resource usage likelihoods. Nevertheless, given the lack of studies 
investigating the role of ethnicity in affecting e-resource usage in Malaysia, no a priori assumptions are posited.

The role of gender in determining web-based instruction usage remains inconclusive. Although Dixon et al. (2014) and van Deursen and van Dijk (2014) note that significant gender gaps exist with respect to Internet access and usage, Losh (2003) finds that gender parity does exist in computer and Internet usage in the United States. Meanwhile, Enoch and Soker (2006) point to the presence of a digital divide among male-female university students in Israel, whereby males who form the dominant group are able to benefit more over the female subordinate group as the differences persist over time. Given these mixed outcomes, no a priori assumptions are hypothesised between gender and e-resource usage.

The educational background of the student may play a role in the likelihood of e-resource usage. This stems from the fact that better educated individuals value such resources more highly than those who are less educated. Better educated persons are also assumed to have greater confidence to navigate new information systems, such as the E-library or LMS. In contrast, those with lower levels of education may face more concerns over ease of use over such e-resources (Claar, Dias and Shields 2014). Thus, it is posited that there exists a positive relationship between education and e-resource usage likelihoods.

It is possible that location of regional centre may influence e-resource usage likelihoods although this factor has not been examined extensively in the literature. This is due to the notion that infrastructure and administrative support from different regional offices may vary between one another (Ping et al. 2012). Students from different regional locations may also possess varying backgrounds in terms of individual exposure to internet knowledge. However, no a priori postulations are assumed on the role of location of regional centre to affect e-resource usage likelihoods.

Previous research has identified income as one of the primary factors in determining differences in access to Internet technology and the knowledge of how to use it (Zhang 2013; Zickuhr 2013; Garcia 2014). This outcome is expected because when affluent levels increase, individuals are able to reap benefits from a broader range of goods and services, including hardware and access to internet services. Since these goods and services may dictate e-resource connectivity, a positive association between income levels and eresource usage is hypothesised.

A student's year of study may also be correlated with usage of e-resources given the different types of workload one undertakes throughout their course of study. As noted by Wolf (2005) and Samson (2015), first year university students are less likely to use library resources compared to their counterparts in their final year of studies. The complexity of subjects or courses undertaken may play a role in determining e-resources usage as those involved in writing extensive term papers will tend to rely more on such references relative to beginning students who are presumably registered for lighter workloads. However, Teoh and Tan (2011) noted that students in their initial years of study may be more likely to use the library than their seniors given that they are more receptive and amenable to library instructions and propaganda. As a result, no a priori conjectures are made with regard to the effect of year of study on e-resource utilisation.

Although studies on the role of programme of study on e-resource usage is not ubiquitous, prior work relating students' academic programme and the use of library resources have 
been featured in the literature. For example, Williams (1995) suggests that library resources may be less relevant for undergraduate courses in the hard sciences compared to other disciplines. This is because programmes in the scientific fields involve practical laboratory or field experiments which may not need as much library reference work compared to those in the fields of Social Sciences and Arts requiring writing activities (Whitmire 2001). Nevertheless, the nature of ODL programmes may also compel Science majors to indulge in e-resource utilisation. The effect of programme of study will be further examined.

Studies have shown that a formal literacy course is pertinent in order to maximise resource utilisation of online databases among users in academic institutions (Edzan 2007; Teoh and Tan 2011; Samson 2014). This stems from the notion that when new users are trained to achieve a certain level of comfort in using those resources, this would lead to less resistance and a higher willingness of eventual usage. Thus, it is envisaged that attendance to orientation courses, where exposure is provided to the various types of e-resources offered by the institution, will enhance future usage likelihoods.

\section{OBJECTIVES AND HYPOTHESES}

The primary objective of this study is to examine the determinants of e-resource usage among ODL university students. In particular, this study aims to identify the effects of socio-demographic and programme-related factors affecting usage likelihoods of two types of e-resources, i.e E-library and LMS, among ODL university students. The following research questions are raised:

(a) What are the socio-demographic factors (e.g., age, ethnicity, gender, education level, income bracket) likely to affect e-resource utilisation?

(b) What are the programme-related factors (e.g., location of regional centre, year and programme of study, attendance to orientation programme) likely to determine usage of e-resources?

Answers to these questions are relevant as utilisation of these two types of e-resources may conceivably be interdependent. From a pragmatic viewpoint, the profiles of eresource users and non-users allow university policy-makers a better understanding of the specific needs and behaviour of each individual student-user.

The following hypotheses are posited in the current study:

$\mathrm{H} 1$ : There exists a significant difference between age and E-library (LMS) utilisation;

$\mathrm{H} 2$ : There exists a significant difference between ethnicity and E-library (LMS) utilisation;

H3: There exists a significant difference between gender and E-library (LMS) utilisation;

$\mathrm{H} 4$ : There exists a significant difference between education level and E-library (LMS) utilisation;

H5: There exists a significant difference between income bracket and E-library (LMS) utilisation;

H6: There exists a significant difference between location of regional centre and E-library (LMS) utilisation;

H7: There exists a significant difference between year of study and E-library (LMS) utilisation;

H8: There exists a significant difference between programme of study and E-library (LMS) utilisation; and 
H9: There exists a significant difference between attendance to orientation programme and E-library (LMS) utilisation.

\section{METHOD}

As typical in many cross-sectional studies, large clusters of respondents may report nonutilisation/participation during the survey period. Such non-occurrences may be due to a variety of reasons, amongst which include economic circumstances, religious prohibitions, social stigma, or a general non-preference for the particular activity. Under these circumstances, the use of the dichotomous-choice Logit model is appropriate in modelling usage likelihoods as its specification allows for monotonic transformations to guarantee that predictions (probabilities) remain in the unit interval (Greene 2007; Teoh and Tan 2011).

\section{The Logit Model}

In general, the Logit model is written as:

$$
\log [P /(1-P)]=\beta_{0}+\beta_{1} X_{1}+\ldots+\beta_{n} X_{n}+\varepsilon
$$

where, $\mathrm{P}=$ probability of a respondent to utilise the WOU e-library and/or LMS e-resources during the past semester; $X=$ explanatory variables hypothesised to influence this probability as listed in Table $1 ; \beta_{i}=$ coefficients for explanatory variables; $\varepsilon=$ stochastic disturbance term; and $\mathrm{P} /(1-\mathrm{P})=$ ratio of probability or odds that the respondent utilises the e-resources.

\section{Data Collection}

Data were collected using prepared questionnaires. A pilot study with 10 respondents from the Johor Bahru regional office was conducted for this initial stage to pre-test the reliability of the questionnaires as well as to ascertain the presence of any potential problems. Based on the pilot study, several parts of the questionnaire were revised for clarity.

Direct interviews were conducted among student respondents randomly selected during study breaks of selected tutorial sessions. The sample was stratified according to ethnicity, gender, location of regional centre, year, and programme of study to reflect the population breakdown of WOU students (Wawasan Open University Annual Report 2013). Since location of regional centre may be a factor in determining e-resource usage, these interviews were conducted at the various WOU regional offices in Johor Bahru, Ipoh, Kuala Lumpur, Kuching, and Penang.

The questionnaire consists of three sections. In the first section, the student's sociodemographic information, such as ethnicity, gender, age, location of residence, and household income were elicited. Section two of the questionnaire contains WOU programme-related information, such as year registered, programme of study, and whether the student attended the orientation session during initial registration. Respondents were then asked whether they utilised the E-library and/or LMS during the past semester. Section three solicits information on the reasons for using or not using the WOU e-resources. A total of 1,192 observations were retained for final analysis after deleting those with incomplete information.

\section{Definition of Variables}

In this study, two separate dichotomous-choice outcome variables are considered based 
on the respondent's responses on E-library and LMS resource usage at WOU. In response to the question, "During the past semester, have you ever used the E-library (LMS) resource provided by WOU?", affirmative $(Y=1)$ and negative $(Y=0)$ responses reflect Elibrary (LMS) resource utilisation.

Selection of variables likely to affect usage likelihoods of e-resource relies on previous studies cited above. The following explanatory variables are hypothesised to influence Elibrary and LMS usage likelihoods: age of respondent in years (Age); ethnicity (Malay, Chinese, Indian, Others); highest level of formal education (Bachelor degree, Sijil Tinggi Pelajaran Malaysia (STPM), diploma, Sijil Pelajaran Malaysia (SPM)); location of regional centre (Johor Bahru (JB), Ipoh, Kuala Lumpur (KL), Kuching, Penang), monthly household income bracket (in Ringgit Malaysia, US\$1.00 = RM4.00 as of 8 May 2016), representing low (RM0-1499, US\$0-374), lower-middle (RM1500-4499, US\$416-1246) upper-middle (RM4500-5999, US\$1125-1499), and high ( $\geq$ RM6000, $\geq$ US\$1500) income earners; year of registration at WOU (Years 1-5); and programme of study (Post-graduate, Liberal Arts/Education, Business, Science). Additional dummy explanatory variables include: gender of respondent (Male) and whether the respondent attended the WOU orientation programme during initial registration (Orientation) (Table 1).

\section{RESULTS}

\section{Characteristics of Respondents}

Definitions and descriptive statistics of variables in the statistical model are provided in Table 1. From the total sample of 1,192 respondents, it is evident that LMS usage (93.6 percent) outweighs E-library utilisation (34.6 percent). About 99.0 percent of (the subsample of 413) E-library users are also LMS users while 90.8 percent of (779) E-library nonusers still utilise LMS. In comparison, only 36.6 percent of (1116) LMS users are concurrent E-library users while only 5.3 percent of (76) LMS non-users engage in E-library.

The average age of the total sample (31.9 years) is comparable to that of the WOU population (29.0 years). Within the E-library sample, the average age of users (33.0 years) is slightly higher than that of non-users (31.4 years). Meanwhile, the average age of LMS users (31.9 years) is lower than that of non-users (32.4 years). The ethnic breakdown of the total sample (8.2 percent Malays, 71.1 percent Chinese, 17.8 percent Indians, 2.9 percent other ethnicities) corresponds to the WOU composition (10.7 percent Malays, 69.6 percent Chinese, 18.7 percent Indians, 0.9 percent other ethnicities). Approximately 47.1 percent of the entire samples are males compared to 50.7 percent for the WOU population. Within the E-library sample, the proportion of male users ( 50.8 percent) outweighs the non-users (45.2 percent). Meanwhile, there are fewer male LMS users ( 46.1 percent) than non-users (63.2 percent).

The majority of the entire sample possess a diploma as their highest level of education (53.4 percent). Students from the regional offices of Johor Bahru (25.0 percent), Penang (24.3 percent), and Kuala Lumpur (22.7 percent) form the bulk of the full sample. The largest income group consists of 59.3 percent earning a monthly household income of between RM1500-4499 (US\$416-1246, lower-middle income group). 
Table 1: Definition and Descriptive Statistics of Variables in the Statistical Model ${ }^{\dagger}$

\begin{tabular}{|c|c|c|c|c|c|c|c|}
\hline \multirow[t]{2}{*}{ Variables } & \multirow[t]{2}{*}{ Definition } & \multicolumn{2}{|c|}{ E-library } & \multicolumn{2}{|c|}{ LMS } & \multirow{2}{*}{$\begin{array}{c}\text { Total } \\
\text { Sample }\end{array}$} & \multirow{2}{*}{$\begin{array}{l}\text { WOU } \\
\text { Population** }\end{array}$} \\
\hline & & User & Non-User & User & Non-User & & \\
\hline \multicolumn{8}{|c|}{ Dependent variables $($ Yes $=1 ; \mathrm{No}=0)$} \\
\hline E-library & One who utilises the E-library during the past semester & - & - & 36.6 & 5.3 & 34.6 & - \\
\hline LMS & One who utilises LMS during the past semester & 99.0 & 90.8 & - & - & 93.6 & - \\
\hline \multicolumn{8}{|c|}{ Continuous explanatory variable } \\
\hline \multirow[t]{2}{*}{ Age } & Age of respondent (years) & 33.0 & 31.4 & 31.9 & 32.4 & 31.9 & 29.0 \\
\hline & & $(8.7)$ & $(8.5)$ & $(8.4)$ & $(10.8)$ & (8.6) & - \\
\hline \multicolumn{8}{|c|}{ Binary explanatory variables $($ Yes $=1 ;$ No $=0$ ) } \\
\hline Malay & Ethnicity is Malay & 9.2 & 7.7 & 8.1 & 10.5 & 8.2 & 10.7 \\
\hline Chinese & Ethnicity is Chinese & 65.6 & 73.9 & 70.9 & 73.7 & 71.1 & 69.6 \\
\hline Indian* & Ethnicity is Indian & 22.0 & 15.5 & 18.0 & 14.5 & 17.8 & 18.7 \\
\hline Others & Ethnicity is Others & 3.1 & 2.8 & 3.0 & 1.3 & 2.9 & 0.9 \\
\hline Male & Gender is male & 50.8 & 45.2 & 46.1 & 63.2 & 47.1 & 50.7 \\
\hline Degree & Highest level of education is degree & 22.8 & 14.6 & 17.2 & 21.1 & 17.4 & - \\
\hline STPM & $\begin{array}{l}\text { Highest level of education is Sijil Tinggi Pelajaran Malaysia } \\
\text { (STPM) }\end{array}$ & 10.2 & 11.2 & 11.0 & 7.9 & 10.8 & - \\
\hline Diploma & Highest level of education is diploma & 48.9 & 55.8 & 54.0 & 44.7 & 53.4 & - \\
\hline SPM* & Highest level of education is Sijil Pelajaran Malaysia (SPM) & 18.2 & 18.4 & 17.7 & 26.3 & 18.3 & - \\
\hline Low income & Monthly household (HH) income RM0-1499 (Low) & 13.6 & 16.9 & 15.0 & 27.6 & 15.8 & - \\
\hline Low-middle & Monthly HH income RM1500-4499 (Lower-middle) & 57.1 & 60.5 & 59.5 & 56.6 & 59.3 & - \\
\hline
\end{tabular}




\begin{tabular}{|c|c|c|c|c|c|c|c|}
\hline Up-middle* & Monthly HH income RM4500-5999 (Upper-middle) & 12.1 & 10.9 & 11.6 & 6.6 & 11.3 & - \\
\hline High income & Monthly $\mathrm{HH}$ income is RM6000 and above (High) & 17.2 & 11.7 & 13.9 & 9.2 & 13.6 & - \\
\hline JB & Regional centre is Johor Bahru & 24.2 & 25.4 & 24.6 & 30.3 & 25.0 & 15.4 \\
\hline Ipoh & Regional centre is Ipoh & 17.2 & 15.8 & 16.6 & 11.8 & 16.3 & 11.2 \\
\hline $\mathrm{KL}$ & Regional centre is Kuala Lumpur & 23.0 & 22.6 & 23.5 & 11.8 & 22.7 & 31.3 \\
\hline Kuching & Regional centre is Kuching & 10.7 & 12.2 & 11.6 & 13.2 & 11.7 & 8.4 \\
\hline Penang* & Regional centre is Penang & 24.9 & 24.0 & 23.7 & 32.9 & 24.3 & 33.4 \\
\hline Year $1^{*}$ & Registered in WOU in 2013 & 37.8 & 31.3 & 33.2 & 38.2 & 33.6 & 24.5 \\
\hline Year 2 & Registered in WOU in 2012 & 21.8 & 23.2 & 22.8 & 22.4 & 22.7 & 21.3 \\
\hline Year 3 & Registered in WOU in 2011 & 20.6 & 22.8 & 22.2 & 19.7 & 22.1 & 21.5 \\
\hline Year 4 & Registered in WOU in 2010 & 8.2 & 11.3 & 10.1 & 11.8 & 10.2 & 17.0 \\
\hline Year 5 & Registered in WOU in 2009 or prior & 11.6 & 11.3 & 11.6 & 7.9 & 11.4 & 15.7 \\
\hline Post-grad & Programme of study is Post-graduate & 22.0 & 11.9 & 15.2 & 18.4 & 15.4 & 14.5 \\
\hline Liberal-Education & Programme of study is Liberal Arts/Education & 9.4 & 10.4 & 10.0 & 10.5 & 10.1 & 11.2 \\
\hline Business* & Programme of study is Business Studies & 52.1 & 57.6 & 55.6 & 56.6 & 55.7 & 49.5 \\
\hline Science & Programme of study is Science and Technology & 16.5 & 20.0 & 19.1 & 14.5 & 18.8 & 24.8 \\
\hline Orientation & Attended WOU orientation programme & 81.1 & 71.4 & 75.4 & 65.8 & 74.7 & - \\
\hline Sample size & & 413 & 779 & 1,116 & 76 & 1,192 & - \\
\hline (\%) & & (34.6) & (65.4) & (93.6) & (6.4) & (100.0) & - \\
\hline
\end{tabular}

${ }^{\dagger}$ Values for continuous variable is sample means (with standard deviations in parenthesis), while values for binary variables are in percentages.

* Reference groups

** Source: Wawasan Open University Annual Report (2013). 
The majority of the total sample (33.6 percent) consists of first year students. In terms of programme of study, the breakdown of the total sample (15.4 percent Post-graduate, 10.1 percent Liberal Arts/Education, 55.7 percent Business Studies, 18.8 percent Science and Technology) corresponds to the WOU composition (14.5 percent Post-graduate, 11.2 percent Liberal Arts/Education, 49.5 percent Business Studies, 24.8 percent Science and Technology). The bulk of the sample respondents (74.7 percent) attended the WOU orientation programme during initial registration.

\section{Logit Regression Analysis}

Results of Logit analysis on E-library and LMS utilisation are provided in Table 2. For Elibrary, the goodness-of-fit tests of Pearson $\chi^{2}$ is $1164.42(P=0.158 ; 1,117$ d.f.), likelihoodratio is 65.97 ( $P=0.000 ; 23$ d.f.), and McFadden's $R^{2}=0.04$. Besides, the model is found to accurately predict 67.45 percent of the outcomes in the sample. The GOF tests of Pearson $\chi^{2}$ for LMS is $1,085.71(P=0.74 ; 1,117$ d.f. $)$, likelihood-ratio is $47.00(P=0.00 ; 23$ d.f. $)$, and McFadden's $R^{2}=0.08$, while the model is found to accurately predict 93.62 percent of the outcomes in the sample. It is therefore concluded that no evidence of incorrect model specification is present for both e-resources and the models fit the data well as one or more of the total effects in the model are important in predicting the probability of the $\mathrm{E}$ library/LMS usage. In checking for multicollinearity among explanatory variables, the variance inflation factor (VIF) is calculated for each variable. A value in excess of 20 is indicative of a multicollinearity problem (Belsley, Kuh and Welsch 2004). The VIFs for all variables in the study are less than 3.0 for all samples considered, with the highest being 2.9 for the lower-middle income group. Thus, no evidence of multicollinearity among the explanatory variables exists. Since Logit parameter estimates do not have direct interpretations, the following discussion focuses on the marginal effects of the respective determinants of E-library/LMS usage.

\section{Marginal Effects}

Marginal effects of explanatory variables on E-library and/or LMS usage are provided in Table 2 . Of the 23 variables considered, only six and nine are significantly associated with E-library and LMS usage, respectively. Specifically, older students are more receptive towards E-library as each additional 10 years in age results in 3.6 percent higher likelihoods of using the resource. However, older students are less amenable to using LMS as each additional 10 years in age results in 1.2 percent lower likelihoods of LMS usage. The hypothesised effect of ethnicity in determining E-library usage likelihood is confirmed in this study as Chinese students are 9.3 percent less likely to utilise the e-resource than Indians. However, the effect of ethnicity on LMS usage is not present. The hypothesised association between gender and e-resource utilisation is confirmed as males are 4.4 percent less likely to utilise LMS compared to females. Better qualified students exhibit higher LMS usage likelihoods as individuals with STPM qualifications are 2.7 percent more likely to use the e-resource than SPM holders. The hypothesised positive association between income levels and e-resource usage is confirmed as students in the low income (RM0-1499, US\$0-415) range are 12.0 percent less likely to utilise LMS than those in the upper-middle income (RM4500-5999, US\$1247-1661) bracket. 
Table 2: Results of Logit Analysis

\begin{tabular}{|c|c|c|c|c|c|c|c|}
\hline \multirow[t]{2}{*}{ Variables } & \multirow[t]{2}{*}{ Mean } & \multicolumn{3}{|c|}{ E-Library } & \multicolumn{3}{|c|}{ LMS } \\
\hline & & $\begin{array}{l}\text { Estimated Coefficients } \\
(\beta)\end{array}$ & $\begin{array}{c}\text { Odds Ratio } \\
\left(e^{\beta}\right)\end{array}$ & Marginal Effects & $\begin{array}{c}\text { Estimated Coefficients } \\
(\beta)\end{array}$ & $\begin{array}{c}\text { Odds Ratio } \\
\left(e^{\beta}\right)\end{array}$ & Marginal Effects \\
\hline Constant & - & $\begin{array}{c}-0.95 * * \\
(0.44)\end{array}$ & 0.39 & - & $\begin{array}{l}3.85^{* * *} \\
(0.86)\end{array}$ & 47.11 & - \\
\hline Age $\div 10$ & 3.19 & $\begin{array}{c}0.16^{*} \\
(0.08)\end{array}$ & 1.17 & $\begin{array}{c}3.56^{*} \\
(1.89)\end{array}$ & $\begin{array}{c}-0.25^{*} \\
(0.15)\end{array}$ & 0.78 & $\begin{array}{c}-1.16^{*} \\
(0.68)\end{array}$ \\
\hline Malay & 0.08 & $\begin{array}{l}-0.17 \\
(0.26)\end{array}$ & 0.84 & $\begin{array}{l}-3.70 \\
(5.59)\end{array}$ & $\begin{array}{l}-0.42 \\
(0.51)\end{array}$ & 0.66 & $\begin{array}{l}-2.28 \\
(3.21)\end{array}$ \\
\hline Chinese & 0.71 & $\begin{array}{c}-0.40 * * \\
(0.17)\end{array}$ & 0.67 & $\begin{array}{l}-9.26 * * \\
(3.91)\end{array}$ & $\begin{array}{c}-0.49 \\
(0.36)\end{array}$ & 0.61 & $\begin{array}{l}-2.07 \\
(1.40)\end{array}$ \\
\hline Others & 0.03 & $\begin{array}{l}-0.36 \\
(0.40)\end{array}$ & 0.69 & $\begin{array}{l}-7.65 \\
(7.89)\end{array}$ & $\begin{array}{c}0.45 \\
(1.09)\end{array}$ & 1.56 & $\begin{array}{c}1.70 \\
(3.42)\end{array}$ \\
\hline Male & 0.47 & $\begin{array}{c}0.22 \\
(0.14)\end{array}$ & 1.25 & $\begin{array}{c}4.96 \\
(3.05)\end{array}$ & $\begin{array}{l}-0.91^{* * *} \\
(0.27)\end{array}$ & 0.40 & $\begin{array}{l}-4.41^{* * *} \\
(1.33)\end{array}$ \\
\hline Degree & 0.17 & $\begin{array}{r}0.20 \\
(0.25)\end{array}$ & 1.22 & $\begin{array}{c}4.52 \\
(5.76)\end{array}$ & $\begin{array}{c}0.26 \\
(0.47)\end{array}$ & 1.29 & $\begin{array}{c}1.10 \\
(1.85)\end{array}$ \\
\hline STPM & 0.11 & $\begin{array}{r}0.15 \\
(0.25)\end{array}$ & 1.16 & $\begin{array}{c}3.35 \\
(5.75)\end{array}$ & $\begin{array}{c}0.76 \\
(0.50)\end{array}$ & 2.13 & $\begin{array}{l}2.70^{* *} \\
(1.37)\end{array}$ \\
\hline Diploma & 0.53 & $\begin{array}{l}-0.13 \\
(0.18)\end{array}$ & 0.88 & $\begin{array}{l}-2.90 \\
(3.93)\end{array}$ & $\begin{array}{c}0.47 \\
(0.31)\end{array}$ & 1.60 & $\begin{array}{c}2.22 \\
(1.49)\end{array}$ \\
\hline Low income & 0.16 & $\begin{array}{l}-0.31 \\
(0.26)\end{array}$ & 0.73 & $\begin{array}{l}-6.65 \\
(5.37)\end{array}$ & $\begin{array}{l}-1.56^{* * *} \\
(0.55)\end{array}$ & 0.21 & $\begin{array}{r}-12.02^{*} \\
(6.26)\end{array}$ \\
\hline Low-middle & 0.59 & $\begin{array}{l}-0.10 \\
(0.21)\end{array}$ & 0.90 & $\begin{array}{l}-2.25 \\
(4.69)\end{array}$ & $\begin{array}{c}-0.76 \\
(0.50)\end{array}$ & 0.47 & $\begin{array}{c}-3.34 \\
(2.11)\end{array}$ \\
\hline High income & 0.14 & $\begin{array}{c}0.12 \\
(0.25)\end{array}$ & 1.13 & $\begin{array}{c}2.71 \\
(5.78)\end{array}$ & $\begin{array}{l}-0.23 \\
(0.62)\end{array}$ & 0.80 & $\begin{array}{c}-1.14 \\
(3.30)\end{array}$ \\
\hline
\end{tabular}


Ng, P.L. \& Tan, A.K.G.

\begin{tabular}{|c|c|c|c|c|c|c|c|}
\hline \multirow[t]{2}{*}{$J B$} & 0.25 & -0.28 & 0.75 & -6.22 & 0.23 & 1.25 & 0.99 \\
\hline & & (0.19) & & (3.95) & $(0.33)$ & & (1.36) \\
\hline \multirow[t]{2}{*}{ Ipoh } & 0.16 & -0.02 & 0.98 & -0.46 & $0.85^{* *}$ & 2.33 & $3.06 * *$ \\
\hline & & $(0.20)$ & & $(4.54)$ & $(0.42)$ & & (1.19) \\
\hline \multirow[t]{2}{*}{ KL } & 0.23 & -0.19 & 0.82 & -4.25 & 0.94 & 2.56 & $3.51 * *$ \\
\hline & & (0.19) & & $(4.07)$ & $(0.42)$ & & $(1.27)$ \\
\hline \multirow[t]{2}{*}{ Kuching } & 0.12 & -0.23 & 0.79 & -5.04 & 0.36 & 1.43 & 1.45 \\
\hline & & $(0.24)$ & & $(4.95)$ & $(0.42)$ & & $(1.51)$ \\
\hline \multirow[t]{2}{*}{ Year 2} & 0.23 & $-0.29 *$ & 0.75 & $-6.38^{*}$ & 0.02 & 1.02 & 0.07 \\
\hline & & $(0.17)$ & & $(3.64)$ & $(0.33)$ & & $(1.51)$ \\
\hline \multirow[t]{2}{*}{ Year 3} & 0.22 & $-0.34^{* *}$ & 0.71 & $-7.45^{* *}$ & 0.23 & 1.26 & 1.02 \\
\hline & & $(0.18)$ & & $(3.66)$ & $(0.35)$ & & $(1.41)$ \\
\hline \multirow[t]{2}{*}{ Year 4} & 0.10 & $-0.59 * *$ & 0.56 & $-11.97 * * *$ & -0.09 & 0.91 & -0.42 \\
\hline & & $(0.24)$ & & $(4.36)$ & $(0.43)$ & & $(2.09)$ \\
\hline \multirow[t]{2}{*}{ Year 5} & 0.11 & -0.28 & 0.76 & -5.96 & 0.69 & 1.99 & $2.52 *$ \\
\hline & & $(0.23)$ & & $(4.65)$ & $(0.50)$ & & $(1.44)$ \\
\hline \multirow[t]{2}{*}{ Post-graduate } & 0.15 & 0.36 & 1.43 & 8.26 & -0.17 & 0.85 & -0.81 \\
\hline & & $(0.23)$ & & $(5.38)$ & $(0.45)$ & & $(2.32)$ \\
\hline \multirow[t]{2}{*}{ Liberal-Education } & 0.10 & -0.04 & 0.96 & -0.83 & 0.03 & 1.03 & 0.13 \\
\hline & & $(0.23)$ & & $(5.02)$ & $(0.44)$ & & (1.96) \\
\hline \multirow[t]{2}{*}{ Science } & 0.19 & -0.22 & 0.80 & -4.79 & $0.62 *$ & 1.86 & $2.41^{* *}$ \\
\hline & & $(0.18)$ & & (3.91) & $(0.37)$ & & $(1.23)$ \\
\hline \multirow[t]{2}{*}{ Orientation } & 0.75 & $0.61 * * *$ & 1.84 & $12.86^{* * *}$ & $0.56^{* *}$ & 1.75 & $2.93^{*}$ \\
\hline & & $(0.16)$ & & $(3.05)$ & $(0.27)$ & & $(1.57)$ \\
\hline Pearson chi-square & & & $1,164.42$ & & & $1,085.71$ & \\
\hline Likelihood ratio & & & 65.97 & & & 47.00 & \\
\hline Prob (LR) & & & 0.00 & & & 0.00 & \\
\hline McFadden $\mathrm{R}^{2}$ & & & 0.04 & & & 0.08 & \\
\hline$\%$ correct predictions & & & $67.45 \%$ & & & $93.62 \%$ & \\
\hline
\end{tabular}

Asterisks $* * *$ indicate significance at the $1 \%$ level, ${ }^{* *}$ at the $5 \%$ level, and ${ }^{*}$ at the $10 \%$ level. Standard errors in parenthesis

Page $\mid 40$ 
Location of regional centre is significantly associated with e-resource usage. Students from the cities of Ipoh (3.1 percent) and Kuala Lumpur (3.5 percent) are more likely to engage in LMS than their peers from the Penang regional office. Meanwhile, year of study is significantly associated with likelihoods of e-resources usage at WOU. Compared to students who are registered in Year 1 (2013), those in Year 2 or 2012 (6.4 percent), Year 3 or 2011 (7.5 percent), and Year 4 or 2010 (12.0 percent) are less likely to use E-library. However, individuals registered in WOU in 2009 or prior (Year 5) are 2.5 percent more likely to use LMS than recent students from Year 1 . Students majoring in Science and Technology (2.4 percent) are more likely to use LMS than Business majors.

Attendance to orientation courses (where exposure is provided to both E-library and LMS eresources) play an important role in its subsequent utilisation rates. Individuals who attended the WOU orientation programme are 2.9 percent more likely to utilise E-library (LMS) than nonattendees. These results support the hypothesis of significant difference between attendance to orientation programmes and e-resource usage likelihoods.

\section{DISCUSSION AND CONCLUSION}

Findings of this study have important implications in identifying the determinants of e-resource usage by ODL university students. Results show that students who are more likely to use the Elibrary consist of older, recent enrolees and participants of the orientation programme; while Chinese students are less likely to use the facility, relative to their respective peers. Meanwhile, LMS usage is concentrated among students who are younger, STPM holders, orientation programme attendees, Science and Technology majors, registered for five years or more, and hailing from Ipoh and Kuala Lumpur. Moreover, low income bracket students and males are less likely to utilise LMS than their respective cohorts. Several observations are noted vis-à-vis usage likelihoods of e-resources among ODL university students.

First, since attendance to orientation programme at the point of registration is a significant determinant for both E-library and LMS usage, this suggests that familiarity with the resource and services offered by the university could encourage further utilisation among students. In corroborating the findings of Edzan (2007) and Teoh and Tan (2011), once students are exposed to the virtues of e-resources, this enables them to form a positive opinion via heightened awareness, thus further enhancing the propensity of future use. Policy wise, university authorities should ensure that attendance to orientation programmes is mandatory for all in-coming first year students. These programmes should highlight the availability of the various resources and services at the university along with providing hands-on support to these new students to ensure maximum resource utilisation.

Second, it should be made known to university officials, particularly those at the library department, that usage of the E-library resource is mostly confined to newer students who may then experience declining interest over the years. This arises as findings of the study indicate that E-library usage likelihoods significantly decline as students spend more time at the university. One possible explanation for this outcome is that, unlike those in their initial stage of university studies, seasoned students depend less on the E-library as they become more aware of the existence of other types of information channels. To ameliorate this issue, efforts should be made to continuously upgrade the E-library materials so as to keep up with the overall needs of the existing students. This includes constant reminders to students about the various facilities offered via Elibrary, such as literature searches of e-journals and e-books, reference materials, past examination papers, inter-library loans, and others. This is also in line with Callison's (1997) assertion that more 
intensive efforts should be made to expand student instruction beyond the one-time induction courses.

Third, location of regional centre is significantly associated with e-resource usage as students in Ipoh and Kuala Lumpur display higher propensities of LMS usage than their Penang cohorts. This outcome is rationalised by the fact that since the main regional office of WOU is located in Penang, students could have easier access to study materials and course-coordinators. Hence, students in Penang might not need to rely on the LMS as much. Additionally, this outcome could be attributed to the greater emphasis on LMS usage by course managers in the Ipoh and Kuala Lumpur regional centres. In terms of practical implications, senior officials in regional offices in other cities (e.g., Johor Bahru, Kuching and even Penang) should take note that there exists room for improvement in emphasising the use of e-resources among their students.

Fourth, as students from the low income bracket are found to be less likely to utilise LMS compared to their upper-middle income peers, these findings may be reflective of the lack of financial resources to establish external connectivity via the internet (Zhang 2013; Garcia 2014). Hence, it is suggested that ODL university policy-makers interested in promoting LMS use amongst its students should invest in both virtual as well as its physical facilities. This includes upgrading the speed and user-friendliness of internet resources as well as to ensure adequacy of personal computers at its various regional centres as part of library infrastructure expansion plans. This is important as results suggest that about 15.8 percent of student respondents are categorised in the low income bracket and may need to rely on university facilities to access the LMS.

Fifth, as current results show that male students are less likely to utilise LMS compared to female students, efforts should be made to encourage further participation among the male student population. Although not within the scope of the present research, it would be prudent for university policy-makers to also examine the retention rates of its male-female student population. If indeed there exists a correlation with gender (particularly males), then LMS non-participation may be a pre-cursor towards drop-out rates at the university.

Sixth, it is interesting to note that type of major is significantly associated with LMS usage likelihoods as present results show that students majoring in Science and Technology exhibit higher propensities to use the LMS than Business Studies majors. This outcome could be indicative of the nature of the Science and Technology programme which is more dependent on the LMS compared to others such as Business Studies. Based on this finding, it is may be prudent for university officials to ensure that all courses and programmes in the university are fully LMS inclined. Students majoring in certain fields should also be encouraged to further utilise the available e-resources.

Finally, the current study represents one of the first attempts at definitively and econometrically examining the determinants of e-resources usage likelihoods in an ODL university setting. With data availability, future studies could replicate our analysis using additional information (e.g., number of hours or time spent using the e-resources, number and level of courses undertaken, faculty recommendation, student grades) to assess the robustness of our findings. A longer survey period over an entire semester would also be beneficial to account for usage peaks and troughs encountered during holidays, examinations and other events as well.

\section{ACKNOWLEDGEMENT}

Research support from the Institute for Research and Innovation, Wawasan Open University is acknowledged. 


\section{REFERENCES}

Andersson, A. 2010. Learning e-Learning: The restructuring of students' beliefs and assumptions about learning. International Journal on E-Learning, Vol. 94, no. 4: 435-461.

Belsley, D. A., Kuh, E. and Welsch, R. E. 2004. Regression diagnostics: Identifying influential data and sources of collinearity. Wiley, New York.

Bennett, S., Maton, K. and Kervin, L. 2008. The "digital natives" debate: A critical review of the evidence. British Journal of Educational Technology, Vol. 39, no. 5: 775-786.

Callison, D. 1997. Evolution of methods to measure student information use. Library \& Information Science Research, 194: 347-357.

Claar, C., Dias, L. P. and Shields, R. 2014. Student acceptance of learning management systems: A study on demographics. Issues in Information Systems, Vol. 15, no. 1: 409-417.

Dixon, L. J., Correa, T., Straubhaar, J., Covarrubias, L., Graber, D. and Spence, J. 2014. Gendered space: The digital divide between male and female users in internet public access sites. Journal of Computer-Mediated Communication, Vol. 19: 991-1009.

Edzan, N. N. 2007. Tracing information literacy of computer science undergraduates: A content analysis of student' academic exercise. Malaysian Journal of Library \& Information Science, Vol. 12, no. 1: 97-109.

Enoch, Y. and Soker, Z. 2006. Age, gender, ethnicity and the digital divide: University student's use of web-based instruction. Open Learning: The Journal of Open, Distance, and e-Learning, Vol. 21, no. 2: 99-110.

Garcia, R. 2014. The relationship between socioeconomic status, course delivery method, and student success at a state college: A single institution analysis. Ph.D. dissertation, Florida International University, FL, USA.

Ghavifekr, S. and Hussin, S. 2010. Management as visionary planning for dealing with systemic change: A case of Malaysian Open Distance Learning Institution. OIDA International Journal of Sustainable Development, Vol. 1, no. 4: 79-85.

Green, L. S., Fethi, A. and Denton, B. 2012. Examination of factors impacting student satisfaction with a new learning management system. Turkish Online Journal of Distance Education, Vol. 13, no. 3: 189-197.

Greene, W. H. 2007. Econometric analysis, $6^{\text {th }}$ ed. New York: Prentice Hall.

Koustriava, E. and Papadopoulos, K. 2014. Attitudes of individuals with visual impairments towards distance education. Universal Access in the Information Society, Vol. 13, no. 4: 439-447.

Losh, S. C. 2003. Gender and educational digital chasms in computer and internet access and use over time: 1983-2000. IT \& Society, Vol. 1, no. 4: 73-86.

Low, A. L. Y., Ong, C. Y. and Low, L. T. 2005. A roadmap of multimedia based learning and online knowledge sharing networks. In Nata, R. (Ed.), Issues in Higher Education. Nova Science Publishers, Inc. pp. 83-114.

Mallinson, B. and Krull, G. 2013. Building academic staff capacity to support online learning in developing countries. Journal of Asynchronous Learning Networks, Vol. 17, no. 2: 63-72.

Mason, R. and Weller, M. 2000. Factors affecting students' satisfaction on a web course. Australian Journal of Educational Technology, Vol. 16, no. 2: 173-200.

McPherson, M. A., and Nunes, J. M. B. 2003. New tutoring skills for online learning: Are e-tutors adequately prepared for e-learning delivery. In Szucs, A., Wagner, E. and Tsolkidis, C. (Eds.), Proceedings of 12th European Distance Education Network Annual Conference on the Quality Dialogue. Integrating Quality Cultures in Flexible, distance and eLearning EDEN 2003, 15-18 June 2003, at Rodos Palace Hotel, Rhodes, Greece.

McPherson, M. A. and Nunes, J. M. B. 2004. The role of tutors as an integral part of online learning support. European Journal of Open and Distance Learning, Available at: http://www.eurodl.org/materials/contrib/2004/Maggie_MsP. html. 
$\mathrm{Ng}$, W. K. and Kong, S. L. 2012. Distance education support systems: Challenges and Opportunities. In Visser, L., Amrault, R. J. and Visser, Y. L. (Eds.), Trends and Issues in Distance Education: International Perspectives. $2^{\text {nd }}$ Edition, IAP Publishing, Inc., USA.

Niehaves, B. and Plattfaut, R. 2014. Internet adoption by the elderly: Employing IS technology acceptance theories for understanding the age-related digital divide. European Journal of Information Systems, Vol. 23, no. 6: 708-726.

Picciano, A. G. 2002. Beyond student perceptions: Issues of interaction, presence, and performance in an online course. Journal of Asynchronous Learning Networks, Vol. 6, no. 1: 21-40.

Ping, T. A., Muthuveloo, R. and Hooi, O. H. 2012. The adoption of technology in service delivery: The case of an Open University. International Journal of Innovations in Business, Vol. 1, no. 5: 411-426.

Rosell-Aguilar, F. 2007. Changing tutor roles in online tutorial support for open distance learning through audio-graphics SCMC. The JALT CALL Journal, Vol. 3, no. 1-2: 81-94.

Samson, S. 2014. Usage of e-resources: Virtual value of demographics. The Journal of Academic Librarianship, Vol. 40: 620-625.

Swart, A. J. 2015. Student usage of a learning management system at an open distance learning institute: A case study in electrical engineering. International Journal of Electrical Engineering Education, Vol. 52, no. 2: 142-154.

Teo, T. 2008. Pre-service teachers' attitudes towards computer use: A Singapore survey. Australasian Journal of Educational Technology, Vol. 24, no. 4: 413-424.

Teoh, Z.M. and Tan, A.K.G. 2011. Determinants of library use amongst university students. Malaysian Journal of Library \& Information Science, Vol. 16, no. 2: 21-31.

van Deursen, A. J. A. M. and van Dijk, J. A. G. M. 2014. The digital divide shifts to differences in usage. New Media \& Society, Vol. 16, no. 3: 507-526.

Wawasan Open University Annual Report. 2013. Student enrolment and graduation. Penang, Malaysia: Wawasan Open University.

Wawasan Open University. 2015a. About Us. Available at: http://wou.edu.my/WOU_vision_ mission_n_values.html.

Wawasan Open University. 2015b. Study with WOU. Available at: http://www.wou.edu.my/ study_Is_Ims.html.

Whitmire, E. 2001. The relationship between undergraduates' background characteristics and college experiences and their academic library use. College \& Research Libraries, Vol. 62, no. 6: 528-540.

Williams, A. P. 1995. Conceptualizing academic library use: Results of a survey of continuing education undergraduates in a small Canadian undergraduate university. Canadian Journal of Higher Education, Vol. 25, no. 3: 31-48.

Wolf, R. D. 2005. Library use and source selection of undergraduate students at the University of North Carolina at Chapel Hill. Master's Paper for the M.S. in Librarian Science degree: 53 pages, University of North Carolina at Chapel Hill, NC, USA.

Wong, T. M. and Liew, T. K. 2013. Malaysia's Wawasan Open University. In Jung, I., Wong, T. M. and Belawati, T. (Eds.), Quality Assurance in Distance Education and Learning: Challenges and Solutions from Asia. SAGE Publications India Pte. Ltd. pp. 199.

Zhang, P. 2013. Digital divides and socio-demographic factors: A longitudinal quantitative study of internet users in U.S. from 2000 to 2010. Ph.D. dissertation, Capella University, MN, USA.

Zhang, W., Perris, K. and Yeung, L. 2005. Online tutorial support in open and distance learning: Student's perceptions. British Journal of Educational Technology, Vol. 36, no. 5: 789-804.

Zickhur, K. 2013. Who's Not Online and Why. Pew Research Centre. Available at: http://www.pewinternet.org/files/oldmedia/Files/Reports/2013/PIP_Offline\%20adults_09251 3_PDF.pdf. 
Page | 45 